\title{
RETE OVARII IN HEIFERS: A PRELIMINARY STUDY
}

\author{
L. F. ARGHBALD, ${ }^{*}$ R. H. SCHULTZ, ${ }^{*}$ M. L. FAHNING, ${ }^{*}$ \\ H. J. KURTZ† AND R. ZEMJANIS* \\ *Department of Veterinary Obstetrics and Gynecology, and \\ $\dagger$ Department of Veterinary Pathology and Parasitology, \\ University of Minnesota, St Paul, Minnesota 55101, U.S.A.
}

(Received 25th March 1971)

Summary. The histological appearance of the cells of the rete ovarii in heifers suggests that this ovarian structure could be secretory in nature. A holocrine type of secretion appears to be involved and is restricted to the dioestrous phase of the oestrous cycle.

According to Arey (1960), the rete ovarii is vestigal in man though retained in the adult woman. Sauramo (1954) reported metaplasia, cyst formation, hyperplasia and adenomatous changes in the rete ovarii of women with advancing age. Hadek (1958) reported the presence of vestiges of the rete ovarii in the ovarian medulla of sheep. Occasionally, these vestiges were enlarged to form sinusoids. O'Shea (1966) observed scanty secretory material in the rete ovarii of dogs in the dioestrous phase of the oestrous cycle and during pregnancy. This material was positive for colloidal iron and stable with hyaluronidase. Donaldson \& Hansel (1968) reported squamous metaplasia of the cells of the rete ovarii in two cows with cystic follicles showing nymphomania.

Ovarian specimens were obtained from both superovulated and control heifers on Days 4, 8, 12 and 20 after ovulation. Ovarian tissue was fixed in $10 \%$ phosphate-buffered formalin, and then dehydrated and embedded in paraffin wax. Sections were cut at $6 \mu \mathrm{m}$ and stained with haematoxylin and eosin, toluidine blue or periodic acid-Schiff (PAS). Staining with PAS was carried out with and without pretreatment of the sections with a $1 \%$ solution of animal diastase at $37^{\circ} \mathrm{C}$ for $1 \mathrm{hr}$.

The histological and histochemical features of the rete ovarii both of the superovulated and the control heifers were similar on each day on which they were studied. The cells of the rete ovarii were located in the ovarian medulla and were composed of oval-shaped nuclei with prominent chromatin and small amounts of light-staining cytoplasm. These cells were arranged both as a single layer and a pseudostratified layer (Pl. 1, Fig. 1). Tube-like and circular arrangements of the rete ovarii were observed. The circular arrangement was reminiscent of the structure of primordial ovarian follicles.

On Day 4, the lumina of the rete ovarii contained eosinophilic material and mononuclear cells (Pl. 1, Fig. 2). The eosinophilic material was PAS-positive, diastase resistant and non-metachromatic. On Days 8 and 12, intraluminal material mixed with necrotic cellular débris was observed (Pl. 1, Fig. 3). No

Approved as Scientific Journal Series Paper No. 7574, Minnesota Agricultural Experimental Station. 
intraluminal material was present on Day 20. The histochemical features of the intraluminal material suggest that it may be composed either of mucoproteins, glycoproteins or very weak proteins.

Since the intraluminal material was present in both superovulated and control heifers, it was presumably not induced by superovulation. The fact that this material was present only during the dioestrous phase of the oestrous cycle was indicative of endocrine influence. It appeared that cells of the rete ovarii were being sloughed into the lumen. This suggests a holocrine type of secretion.

This work was supported by funds from the Minnesota Agricultural Experiment Station budget and funds from the Hill Family Foundation for which gratitude is expressed.

\section{REFERENCES}

AREY, L. B. (1960) Developmental anatomy, 6th edn. Saunders, Philadelphia and London.

Donaldson, L. E. \& Hansel, W. (1968) Cystic corpora lutea and normal and cystic Graafian follicles in the cow. Aust. vet. 7. 44, 304.

HADEK, R. (1958) Morphological and histochemical study on the ovary of the sheep. Am. F. vet. Res. $19,873$.

O'SHEA, J. D. (1966) Histochemical observations on mucin secretion by the subsurface epithelial structures in the canine ovary. 7. Morph. 5, 347.

Sauramo, H. (1954) Development occurrence, function and pathology of the rete ovarii. Acta obstet. gynec. scand. 33, 29.

\section{EXPLANATION OF PLATE 1}

Fig. 1. Photomicrograph of rete ovarii 4 days after ovulation showing single-layered (1) and pseudostratified (2) arrangements of epithelium. H \& E stain. $\times 350$.

FIG. 2. Photomicrograph of rete ovarii 4 days after ovulation showing homogenous material and mononuclear cells in the lumen. The circular arrangement (CA) is reminiscent of the structure of a primordial ovarian follicle. $\mathrm{H} \& \mathrm{E}$ stain. $\times 350$.

FIG. 3. Photomicrograph of rete ovarii 8 and 12 days after ovulation showing necrotic cellular débris and homogenous material in the lumen. H \& E stain. $\times 350$. 


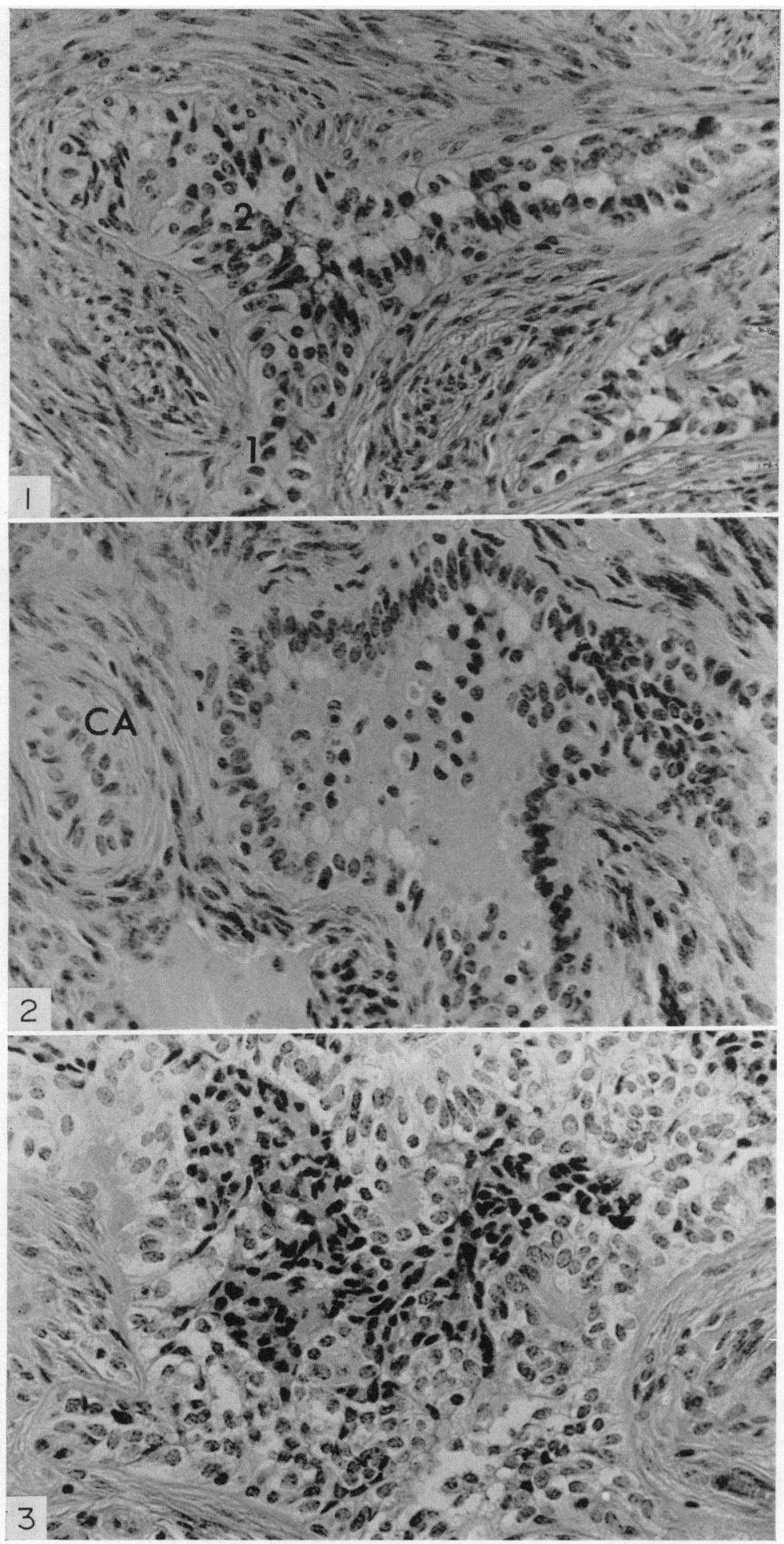

